\title{
PREPARATION AND SUBMISSION OF THE NOMINATION FILE OF THE OASIS OF FIGUIG (MOROCCO) FOR INSCRIPTION ON THE WORLD HERITAGE LIST: IMPACTS AND USES OF A GIS
}

\author{
Laurence GILLOT** and André DEL+, \\ *Université Denis Diderot, Paris, France, \\ +Espace Virtuel de Conception Architecturale et Urbaine (EVCAU), Ecole d' architecture Paris Val \\ de Seine, Paris , France.
}

Keywords: GIS; data communication; archaeological and architectural data

\begin{abstract}
At the request of the municipality of Figuig, a team of scientists, working under the supervision of Professor Jean-Pierre Vallat of the University Paris Diderot and the School of architecture Paris-Val-de-Seine, was entrusted with the task of drawing up and inventory and making an analysis of the cultural properties of the oasis. This program has been led in order to assist the local authorities in the preparation of the nomination file for the inscription of the oasis on the World Heritage List. The oasis is regarded as a matter of fact as a cultural landscape, composed by an important cultural heritage, both material and immaterial. Figuig is indeed characterized by a rich architecture, particularly the ksour (fortified villages) with mud brick houses. Figuig also comprises a palm grove irrigated by a complex network of canals and "foggaras" (pits). Moreover, all the individual and collectives practices connected to the palm grove and to the ksour constitute an important immaterial cultural heritage. The bulk of scientific data (from archaeological, geographical, historical, anthropological investigations) calls for a coherent archiving in order to insure the heritage, environmental and tourism management of the oasis. For this purpose, a GIS would be useful. As a scientific and management tool, the GIS is a precious device which makes it possible to produce thematic (archaeological, historical, touristic, etc.) mappings and inventories. In parallel with these scientific initiatives, the training of the various stakeholders in the practice of the GIS is being developed. Individuals from the municipality, the cooperation offices and the tourism sector are thus developing new competencies. In this respect, the GIS should be a shared tool with multiple applications: scientific researches, heritage management, urban development, tourism management, etc. In this context, this paper sets to analyse the stakes, perspectives and applications of the GIS regarding the necessary development of the oasis whilst protecting its heritage, and ensuring good governance, transparency and justification in the framework of generally binding protective measures.
\end{abstract}

\section{THE OASIS OF FIGUIG AND THE URGENCY OF PROTECTION}

Figuig is an oasis situated in the south eastern tip of Morocco, approximately $400 \mathrm{~km}$ south of the Mediterranean Sea and $7 \mathrm{~km}$ away from the Algerian city of Beni Ounif. However the border between both countries is closed today, resulting in the isolation and enclosing of the city. Consequently, Figuig has gone through an important demographic exodus and a drastic reduction of its resources. One of the consequences of this exodus is an important degradation of the heritage, thereby making its classification as national and world heritage even more essential. At present, Figuig is constituted by an urban nucleus consisting of seven «ksour» (Laâbidate, Lamaïz, Hammam Foukani, Hammam Tahtani, Loudaghir, Ouled Slimane and Zenaga) and of more recent districts. The Ksour are distinct practically autonomous communities. Every ksar possesses its own area of palm grove shared by families who exploit small plots of land surrounded with walls, "the gardens". The oasis of Figuig is a coherent, material and cultural set, based on the complementarity between the architecture and the spatial organization of the ksour, the palm grove and its irrigation system, and all the social and cultural practices, which constitute an immaterial heritage of a great importance. The society of Figuig has developed a particular mudbrick architecture reflecting its organisational structures. Figuig's material heritage is rich, both from an architectural and archaeological point of view: great walls, ramparts, watchtowers, mosques, mausoleums, irrigation channels, as well as rock drawings. In all, the oasis is a valuable natural and environmental heritage, as witnessed by its water springs and palm grove. But this heritage suffers a lot of degradation. In this context, the scientists' team supervised by Professor Jean-Pierre Vallat of the University Paris Diderot was contacted by Figuig's municipality, almost 5 years ago, to assist it in its heritage protection policy, concretized by its will to inscribe the oasis on UNESCO's World Heritage List (WHL). The Master degree " City, Architecture, Heritage", co-organized by Paris 7 (UFR GHSS) and the School of Architecture Paris Val-de-Seine (ENSAPVS) was involved from the outset. Numerous students participated in the architectural recording works, in archaeological excavations and in the study of the UNESCO submission file. This diversity of activities and researches 
made a coherent filing essential to insure the reproduction of the data and to produce the necessary multidisciplinary analyses. The mapping of the ksour, in order to allow their protection and visit, and the cartographic analysis of the evolution of the palm grove made it imperative to implement a shared GIS. Beyond its analytical capability, the GIS is a precious device making it possible to produce useful thematic maps. This paper thus discusses the methodology and the uses of the GIS, particularly in the context of the preparation and submission of the nomination file of the Figuig's oasis on the World Heritage List, and more widely in the context of the heritage, environmental, tourist and urban development management of the oasis.

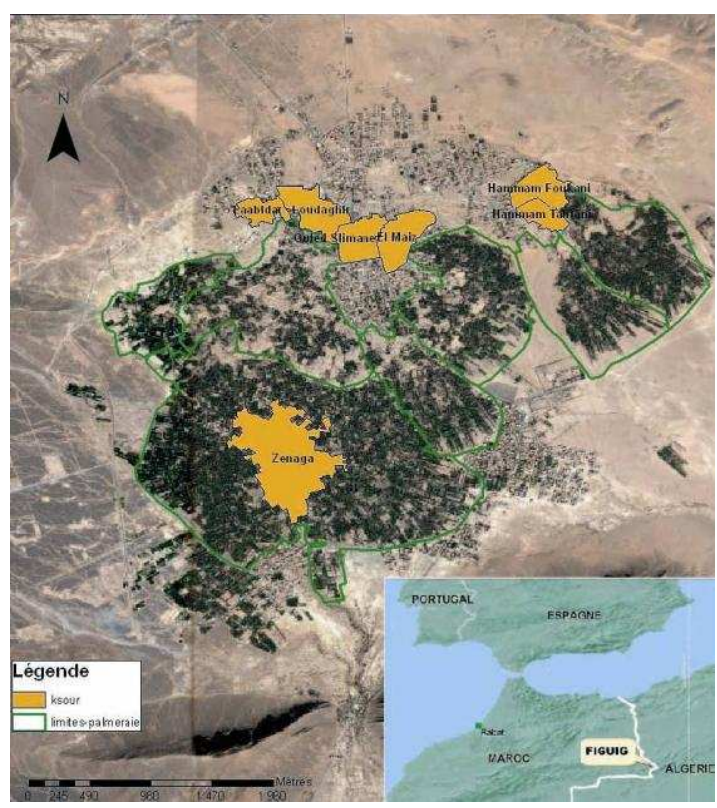

Figure 1: Map of Figuig and its ksour (A. Del and N. Goumeziane)

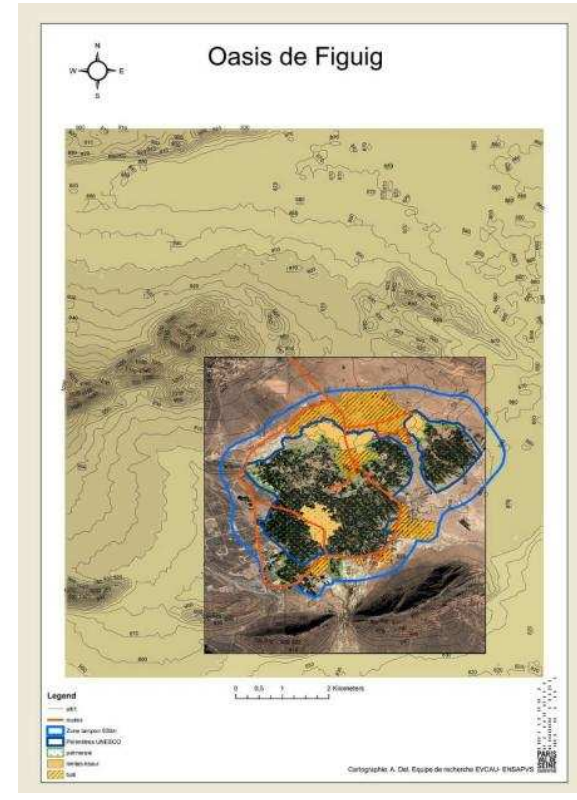

Figure 2: Altimetric map and protection perimeter

\section{STUDIES AND PRODUCTION OF THE NOMINATION FILE OF THE OASIS OF FIGUIG (MOROCCO) FOR INSCRIPTION ON THE WORLD HERITAGE LIST}

For the purposes of the nomination file, the French team considered at first the type of available and relevant sources and then thought about the way of assembling the information collected. In this context, the GIS was considered as a tool suitable for arranging a set of diverse and scattered information in a logical way. First, we shall present the available sources and then describe the methodology applied to assemble these data and establish cartographic databases.

\subsection{Sources}

\subsubsection{Historical Sources}

The textual sources are mainly constituted by travellers' accounts published since the Renaissance. The travellers, Arabic first, then Europeans, who crossed the caravan roads of the Sahara, usually stopped in the oasis of Figuig. Most of these accounts describe an expanding oasis, constituted by a variable number of ksour throughout the times; this illustrates the permanent stakes connected with the appropriation of water and the resulting conflicts. Archives relating to Antiquity and the Middle Ages in the region are lacking. The archaeology makes it however possible to fill these gaps, and we shall deal later with the need to order and compare the data supplied by archaeological excavations to the various categories of sources presented here. Among the first travellers to have described the oasis, Ibn Khaldoun $(1332-1406)^{1}$ and Léon l'Africain $(1488-1550)^{2}$ gave brief descriptions of Figuig, which was then part of the Zianide

\footnotetext{
${ }^{1}$ Ibn Khaldūn (Abū Zayd 'Abdu r-Rahman bin Muhammad bin Khaldūn Al-Hadrami, May 27, 1332 AD/732 AH - March 19, 1406 AD/808 AH) was an Arab historiographer and historian born in North Africa in present-day Tunisia and is sometimes viewed as one of the forerunners of modern historiography, sociology' and economics.

2 Jean-Léon L'Africain (El Hasan ben Mohammed el-Wazzan ez-Zayyâti) was a traveler and a fine political negotiator. In 1518, captured by the knights of the order of Saint Jean, he is presented as a gift to Pope Léon X, who has him catechized and baptized under his own names, Jean Léon.
} 
Kingdom. Travel stories for the $\mathrm{XIX}^{\text {th }}$ and $\mathrm{XX}^{\text {th }}$ centuries are more numerous. Among the French and German travellers, Gerard Rohlfs (1831-1896) ${ }^{3}$ and Jakob Schaudt (1865-1940) ${ }^{4}$ were the first ones to have visited Figuig. After them, Isabelle Eberhardt (1877-1904) $)^{5}$, adventuress and journalis, also visited the oasis of Figuig at the beginning of the $\mathrm{XX}^{\text {th }}$ century. Another traveller, Anne Levinck ${ }^{6}$, novelist and organizer of literary salons in Paris, published in an article in 1885 the account of her journey to Figuig, although certain historians have strong doubts in this regard (see map below). Among the textual sources, two other overlapping categories have attracted our attention; the "geographical" sources and the "military" sources. First of all, French geographers of the beginning of the $\mathrm{XX}^{\text {th }}$ century led researches on the oasis of Figuig, mostly published in the Annals of Geography. As an example, the article of Émile-Félix Gauthier $(1864-?)^{7}$, professor at the University of Algiers, reports oral information relating to the history of Figuig and to the conflicts over the appropriation of water resources in the palm grove. In addition to the text itself, the article also contains a map, which we shall deal with later ${ }^{8}$. The archives of the French army and the colonial administration constitute another type of invaluable textual sources in relation with the previous ones. Geographer E.-F. Gauthier and geologist Louis Gentil thus maintained narrow links with the French army. These military archives do not only deal with strategic issues but also look at societies, their lifestyles and practices. Finally, the various archives of the municipality represent a last category of textual sources. An inventory, classification and translation of these documents should be carried out in the future. After all, Figuig seems to have been a source of inspiration for a lot of travellers, geographers and other intellectuals, as can be seen in the numerous studies on the society, the economy and the culture. But all these rich and scattered archives only offer partial information on the oasis the accuracy of which is hard to ascertain. These data are however precious to study the landscaped evolution of the oasis within the framework of the UNESCO nomination file and the management of the oasis. Indeed, by comparing these sources with other types of data, we could identify the transformations, maybe even the damages, of the palm grove and suggest a rehabilitation of this valuable natural and cultural heritage.

\subsubsection{Iconographic sources and ancient maps}

The iconographic sources are mainly constituted by photos and postcards published since the beginning of the $\mathrm{XX}^{\text {th }}$ century, while engravings and drawings of the previous periods are rare. Most of these sources are available with the inhabitants, in the archives of the municipality of Figuig and on the Internet. In this respect, the dissertation of Master's degree of Gwenaëlle Janty, made within the framework of the French researches in Figuig, collected an important collection of ancient photos, which were, to the extent possible, located on the present site. As regards the ancient maps, numerous cartographic representations do exist in various scales and diverse dates. But or they raise simplistic representations without real dimension, or they are in too small scales to contain relevant information. These maps are never in a modern reference system. In order to use them, it is thus necessary to re-project them in a known reference system. For that purpose, besides the qualities of precision of the initial map and its reproductions, over which we have no control whatsoever, we need to locate, without ambiguity, places and landmarks recognizable beyond any doubt both in the ancient map and in the reference system used for the whole GIS.

\subsubsection{Cartographic References}

The 1983 topographic plan is the first to be based on source data. The plan was realized by the SMPT of Rabat for the Delegation of the housing environment and the town and country planning of the Province of Oujda. The plan is crossruled in "Lambert Nord Maroc". The French team also realized an aerial view in 2008 by extracting 20 Google Earth "shots" with a constant zoom level equivalent to the perception of an air vision from $2000 \mathrm{~m}$. The projection of these two views in a coherent reference system is essential for the analysis of the evolution of the palm grove, in particular for the representation of the system of irrigation (see below).

\footnotetext{
${ }^{3}$ Friedrich Gerhard Rohlfs (been born on April 14th, 1831 in Bremen and died on June 2nd, 1896) was a German geographer and explorer of Africa. He wrote numerous works on Morocco and the North of Africa.

${ }^{4}$ Converted to the Islam, Jakob Schaudt explored Morocco for several years, and brought back to the Minister of Germany in Tangier, numerous samples of ores of all kinds.

${ }^{5}$ Isabelle Eberhardt (17 February 1877 - 21 October 1904) was a Swiss explorer and writer who lived and travelled extensively in North Africa.

${ }^{6}$ Anne Levinck is Suzanne Lambert's literary pen name, born in Lyon in 1851, died in Algiers in 1898.

7 Emile-Félix Gautier was born in Clermont-Ferrand on October 29th, 1864. Named professor to the School of the Letters of Algiers, he embarks on the exploration of Sahara. He pulled in 1908 a fundamental work " Algerian Sahara " which renews the geography of the big desert.

${ }^{8}$ E.-F. GAUTHIER, « La source de Thaddert à Figuig », Annales de Géographie. 1917, t. 26, n ${ }^{\circ}$ 44. pp. $453-466$.
} 


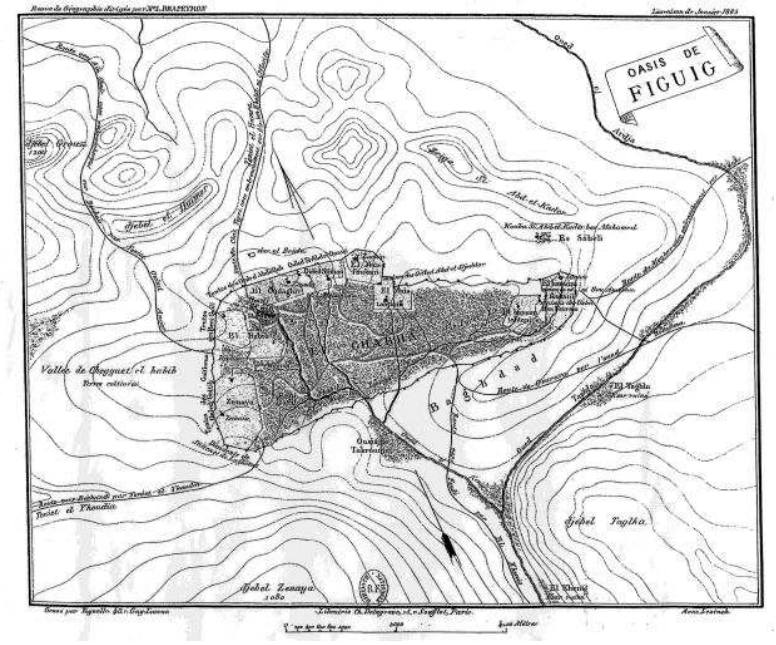

Figure 3: Ancient map by Levinck (1885)

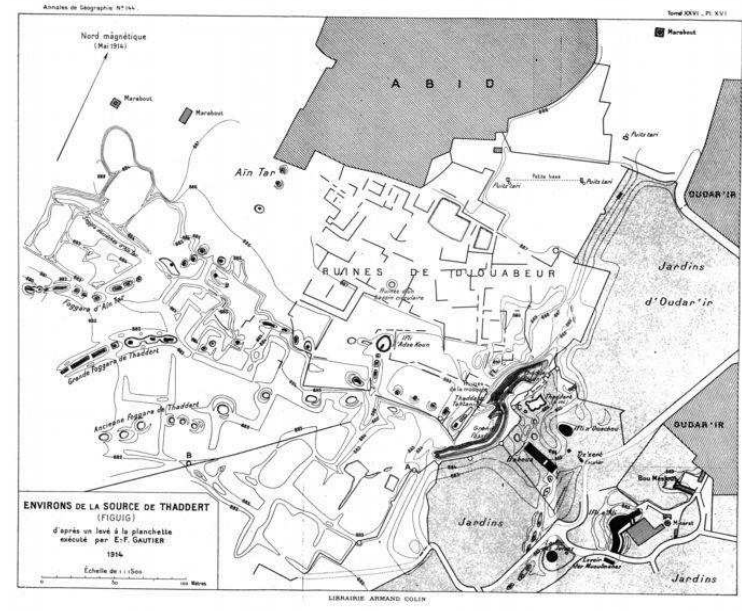

Figure 4: Topographical map by Gauthier (1914)

\subsubsection{Oral Sources}

An important part of the sources used by historians, geographers and archaeologists are oral and bound to the memory Figuig's inhabitants. Recording this memory is very important and is currently in progress through systematic enquiries. These enquiries are registered by dictating machines and should be re-transcribed in the future. Ordering the data collected and reconciling it with other sources is a necessity.

\subsubsection{Archaeological Sources}

Archaeological excavations led by Jean-Pierre Vallat's team since 2005 in different sites in the oasis (Ksar Loudaghir and Ksar Ouled Jaber) resulted in the gathering of a rich and varied documentation. At the level of the excavated material, the missions brought to light Hebrew manuscripts, diverse fragments of ceramic, metallic objects, etc. It is more and more imperative to draw up an inventory of this material in order to study it and interpret it, which would make it possible to establish a timeline in the occupation of the palm grove since the Antiquity. Besides, the other data produced by the archaeologists must be stored, inventoried and combined to other sources, in particular the plans drawn up during the excavations (plans of ksar, of houses, etc.), as well as all the notes drafted during the excavations and in connection with the stratigraphic and topographic units excavated.

\subsection{Constitution of the GIS}

The name "Geographical Information System" covers two aspects: a set of information gathered by an assembly of coherent spatial references (which in a more explicit way means SIRS: System of Information with Spatial Reference) and one or several specific software(s) capable of managing and restoring these sets of information by referring at the same time to their two constituents: thematic and geographical. In both cases, a GIS is intended to gather and to allow the analysis and the restitution of a set of information relating to the same territory.

\subsubsection{Unification of sources in a single geographical reference system}

The geographical situation of the study as well as its frame was not appropriate to make available homogeneous and good quality sources, particularly cartographic ones. The GIS has the potential of allowing geographical unification and sharing of information between entities. In addition to the mapping capabilities which are the most visible ones, we have widely used the processing resources and digital organization of the information offered by the GIS. Three cartographic sources were available in heterogeneous reference tables: topographic plan of 1983 in "Lambert Nord Maroc", the 2008 aerial view stemming from Google Earth in coordinates WGS84 and the outlines of networks on a crisscrossed map, but without an explicit reference system. The unification in the same system of these various maps took place in several stages. 14 boards of the topographic plan were scanned and assembled by curling on the basis of coordinates common to two successive boards. This assembly is at the same time geo-referenced by the identification of known landmarks to which we assign coordinates. The assembled and geo-referenced topographic plan is used as a reference map to which we associate, according to a similar procedure, aerial views and maps of networks. The residues of adjustment of the wedging algorithm are archived in metadata associated with every map, and they constitute a quality indicator of that (Grosso E., 2009). 


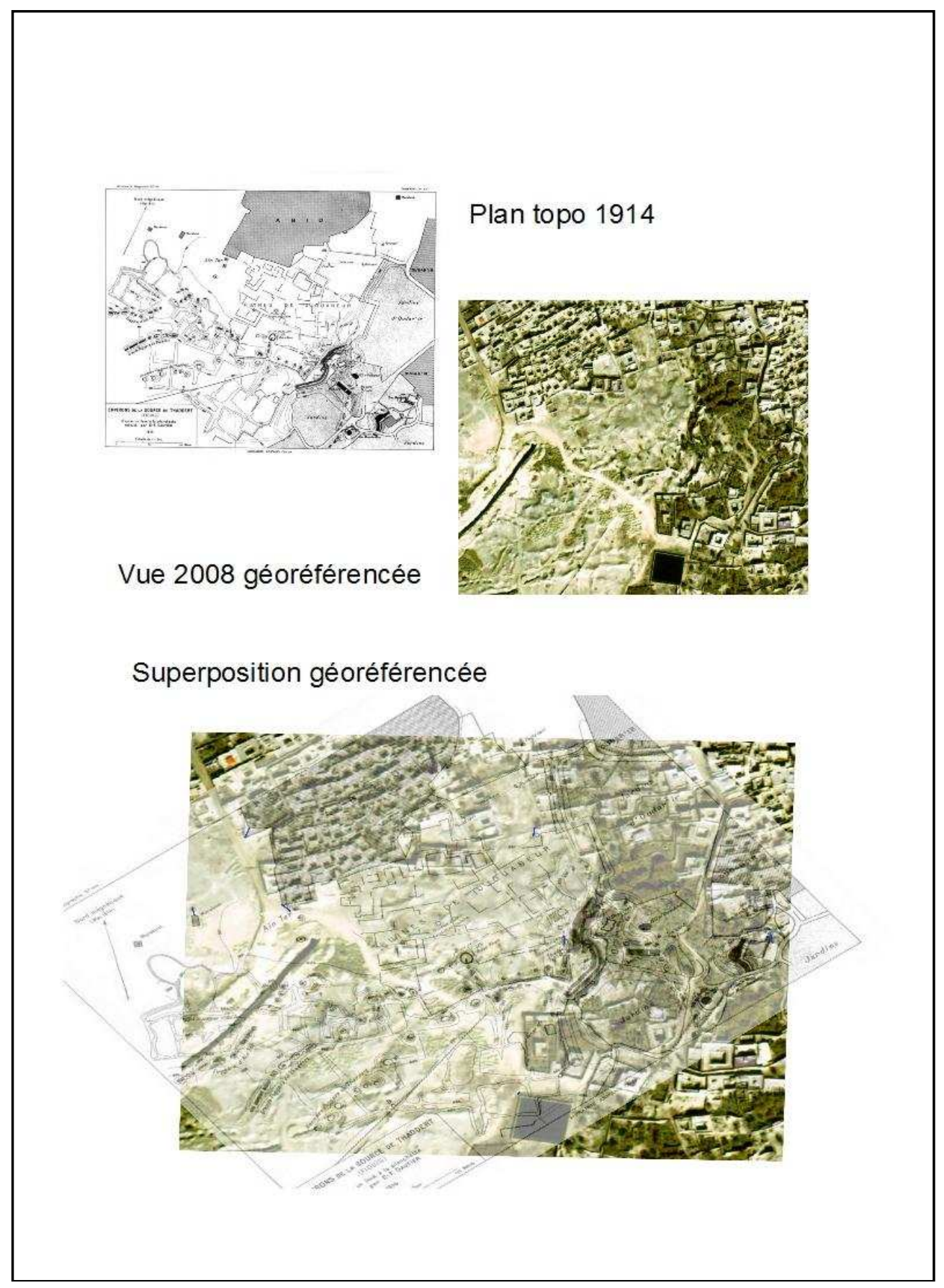

Figure 5: Cartographic sources and assemblage

\subsubsection{Sharing of the assigned information}

A GIS is based on the principle of systematic individual association of a set of information (the attributes) in every realization of the geographical entities. This duality database/maps makes it possible to share these attributes between all the objects of the same geographical reference system. For example, we allocate the attributes of a ksar to all the gardens whose polygons of plots of land are contained in the polygon which delineates the palm grove of the ksar. For the allocation of the attributes of a network in a garden, the procedure consists of two stages. For the analysis of the impacts of the irrigation on the gardens of the palm grove, we build, around every section of network, a polygon (corridor or buffer) to associate, by intersection, the attributes of networks with gardens. The information is mainly grouped together at the level of the plots of land-gardens which constitute the nucleus of the information system (which also corresponds to a physical reality). 


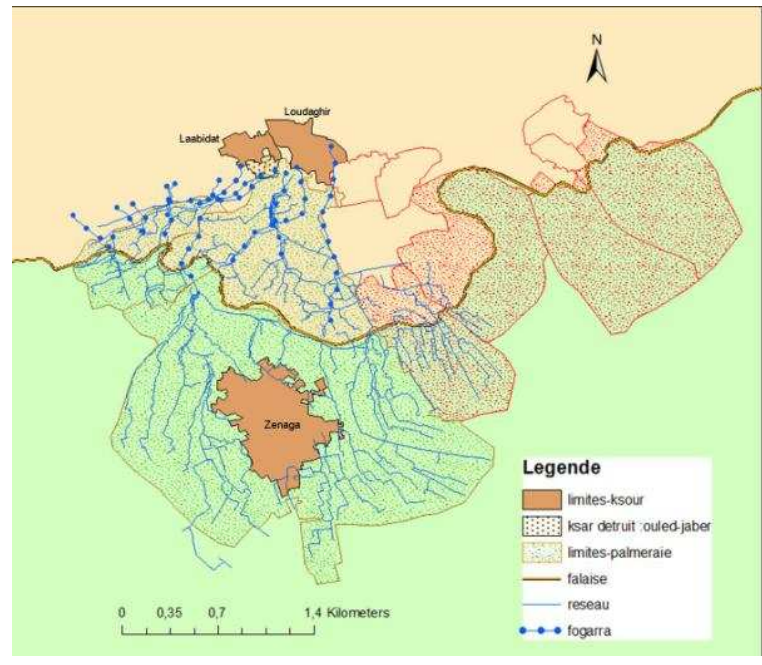

Figure 6: Ksour and irrigation networks (G. Janty)

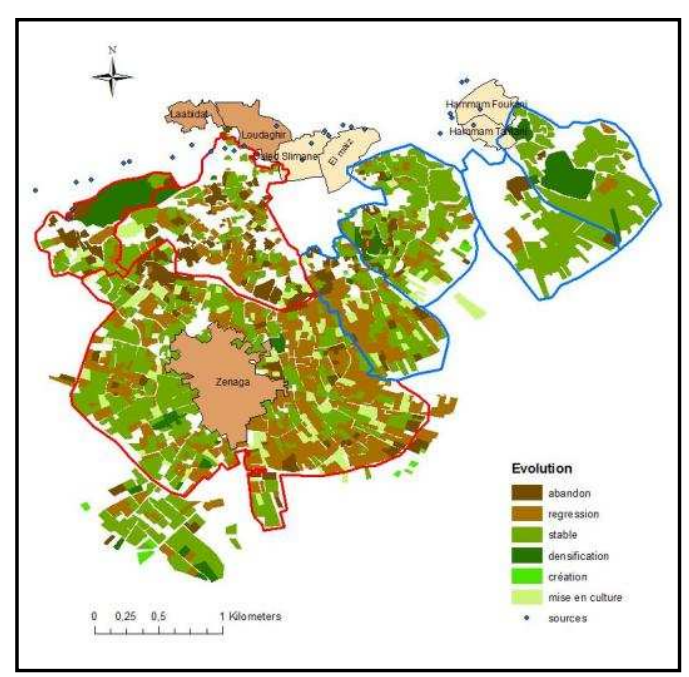

Figure 7: Landscape transformations (G. Janty)

\section{RESULTS AND USES OF THE GIS}

\subsection{Archaeological use}

The application of the GIS in the archaeological domain turned out to be very useful in the programming of archaeological excavations as well as in the interpretation of the data which arose from it, as witnessed by the campaign of the ksar Ouled Jabar in 20099. The qsar of Ouled Jaber is on the plateau of Figuig and peaks between $907,40 \mathrm{~m}$ and $903.10 \mathrm{~m}$. At the edge of the plateau, it overhangs the palm grove and is situated between the qsours of Loudaghir and Laâbidate. At first, the information collected only made it possible to draw up a thematic mapping making proposals about the location of historic and geographical objects. Due to the lack of data (in particular a too strong disparity of the data), we could not finish the geodatabase, which only relates at this stage to the sector of Ouled Jaber. Also, this geodatabase was mainly designed for the purposes of heritage management and in order to give advice to Figuig's municipality in respect of the rehabilitation of the site, at present transformed into a rubbish tip. The GIS makes it therefore possible to emphasize the historic and cultural interest of the site by giving keys to interpretation of vestiges still in position. The work of collection and creation of data was carried out in three phases. The first stage of the work consisted in the collection of planimetric maps and their georeferencing (see above). Georeferencing was realized from a GPS points scatter and points collected from Google Earth. Once this had been carried out, photo-interpretation of the Google Earth image took place. Two days of prospection completed this first interpretation to characterize and locate the vestiges and appearing structures of the site. This work made it possible to bring to light a strong degradation of the state of preservation of the ruins between 1917 and 2009, underlining the urgency to draw up an inventory and to encourage the municipality to make decisions for their preservation. So, on a scientific level, the GIS made it possible to identify two distinct entities, the first one corresponding to the palm grove and the other one to the residential area. A coherent plan in the western and northern part was identified and could correspond to a cob wall, formed by an enclosure, three towers and two doors. The hypothesis of a third door in the western part also seems to emerge. The confrontation with the plan of 1917 led to rectify the plan of the surrounding wall to make it pass in the ksar of Laâbidate. The following campaigns led in October, 2010 and April, 2011 aimed at locating ruins and places represented on photographs and ancient maps with a view of drawing up a map of the archaeological potential of the whole oasis, on the model of what was made for the ksar of Ouled Jaber. For example, the map by Anne Levinck presented above could, in spite of its unorthodox character from a topographic point of view, contain relevant information in respect of the location of disappeared or buried structures. Another application is to associate the GIS with the works led for the digital restoration of the mosque of the ksar, and in the longer term, to allow a restoration of the ksar in its initial stage before abandonment and degradation.

\footnotetext{
${ }^{9}$ R. GonZalez Villaescusa et C. PICHARD, Rapport préliminaire de fouille : Première évaluation du potentiel archéologique du qsar Ouled Jaber (FIGUIG), (7 octobre - 20 octobre 2009), Paris.
} 


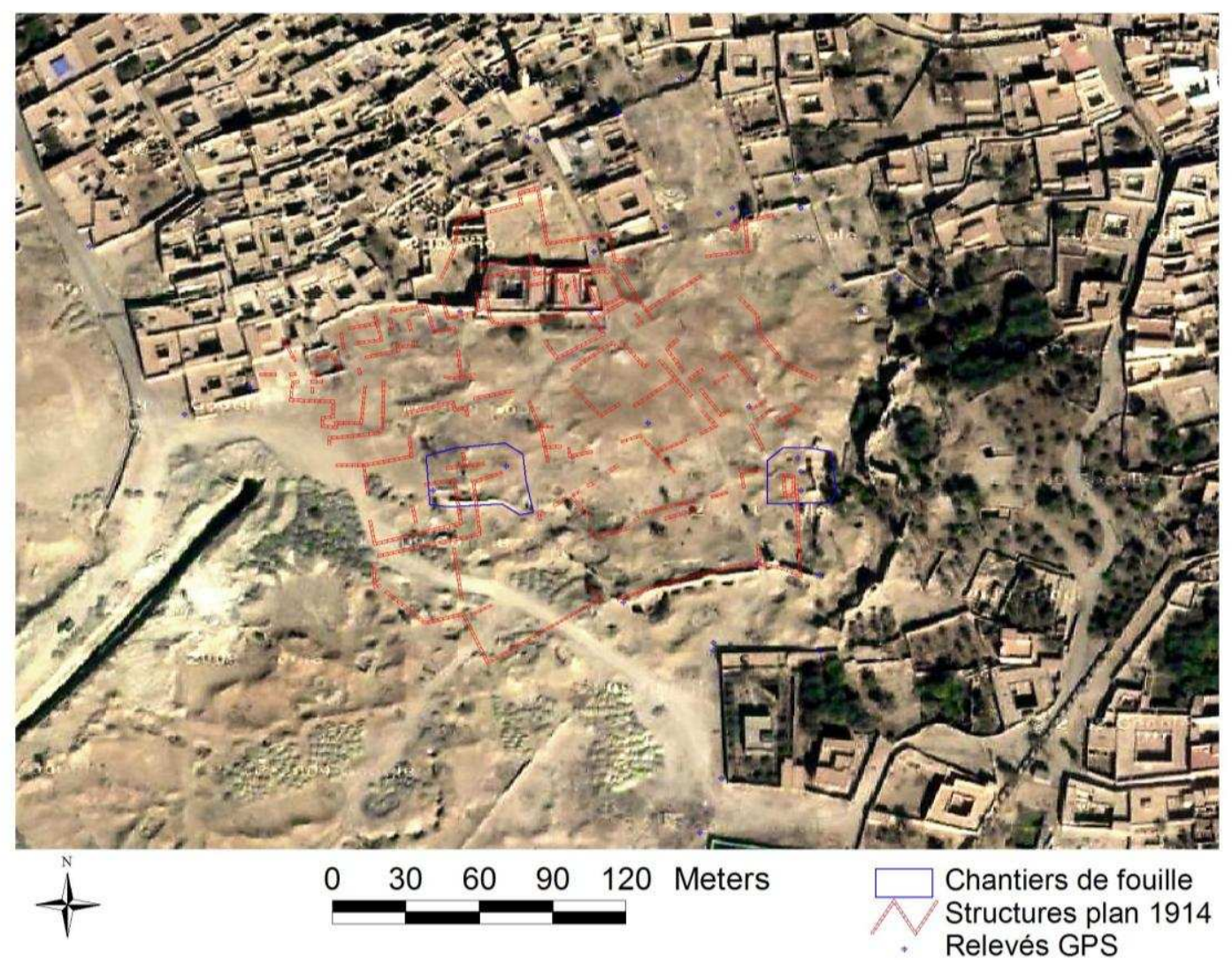

Figure 8: Excavation site of Ouled Jaber (C. Pichard)

\subsection{Heritage management use}

The GIS makes it possible to structure the inventory of buildings and remarkable places of the oasis. Within the framework of the preparation of the nomination file for the inscription of Figuig on the WHL, the GIS was the support for the consideration in respect of the demarcation of the perimeter of protection and the buffer zone, which took place in three stages. The first discussions with the municipality of Figuig led to a first proposition regarding the perimeter. The transfer of this perimeter in the GIS and the spatial parallel made between the perimeter and all the patrimonial elements stemming from preliminary studies, highlighted its inadequacy, in particular in the central part of the oasis, which is the administrative district. A second perimeter was proposed and accepted for the submission file. For the buffer zone, a digital treatment made it possible to determine a limit 200 meters away from the proposed perimeter. This automatic treatment did not take into account of the realities of the urban expansions of the oasis and it was therefore necessary to make several changes, most of them by extension of the perimeter. But after several iterations it did not seem justified to maintain such a perimeter: little or no "alive" parts of Figuig are outside the buffer zone. The idea to propose the extension of the zone to the whole oasis is finally accepted (see above, fig.2).

\subsection{Developmental use}

The GIS could accompany the unavoidable development of the oasis while protecting its heritage, as shown in the study carried out to identify the most suitable sites for welcoming a solar energy firm. Three sources were used: the altimetric data of the oasis, the location of the main ancient buildings and the perimeter of protection proposed in the submission file for the inscription on the WHL A first altimetric data processing has made it possible to build a digital terrain model (DTM). From the DTM we establish the map of exposure to the sun. The geographical orientation is first calculated for every surface unit. Surface units suitable for receiving solar panels are then selected: East, South-East, South, SouthWest, West (degraded of yellow on the left map). We finally calculate zones of no co-visibility where it is possible to establish constructions that are not visible from the main heritage buildings (in green on the right map).

The logical combination of both maps: [\{convenient zones\} X not visible zones $\}$ makes it possible to determine the most suitable perimeter for installing solar panels. 

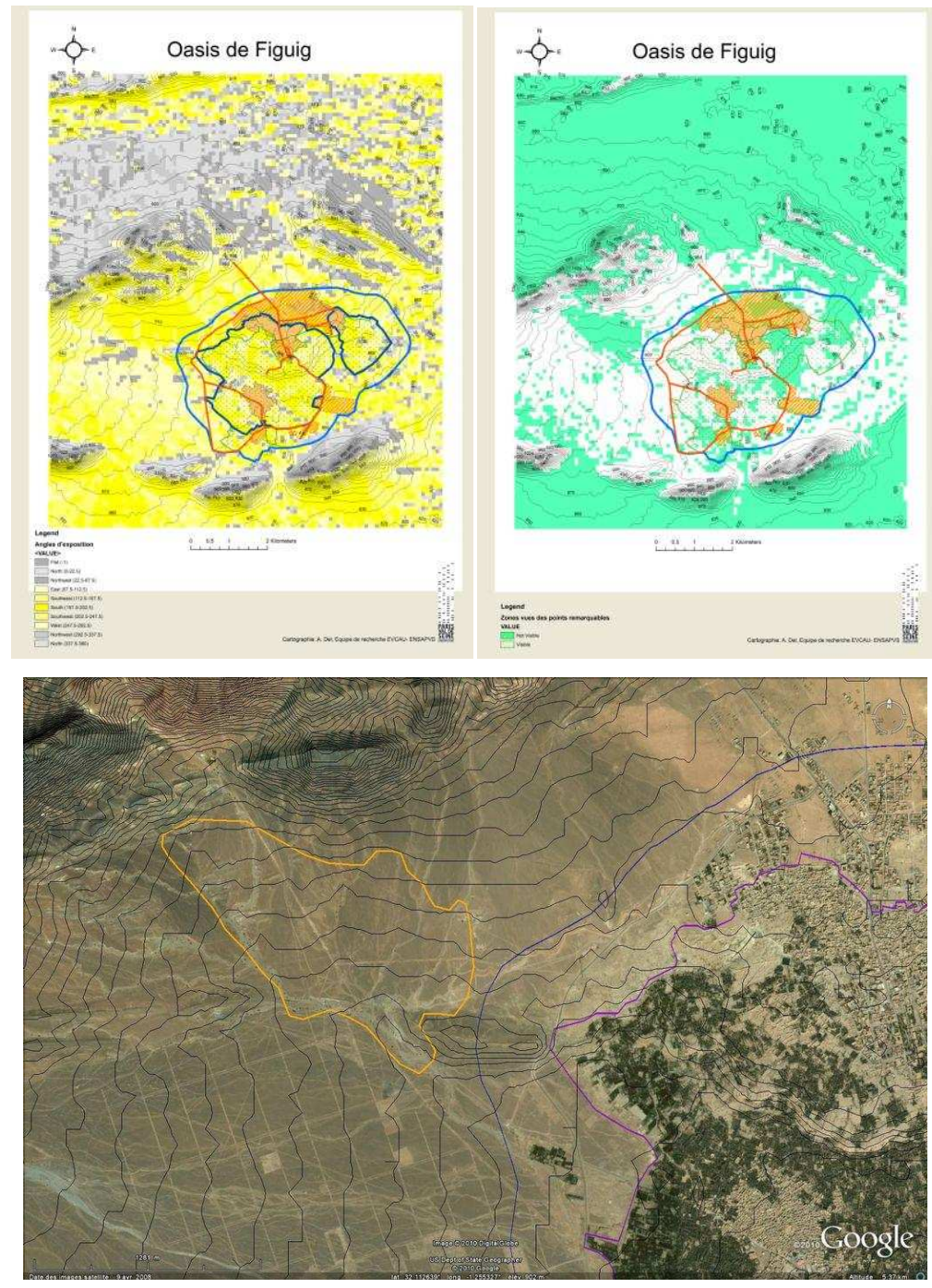

Figure 9: Co-visibility and suitable zones for exposure

\subsection{Touristic use}

Anxious to develop a sustainable tourism, the municipality of Figuig promotes a reasoned development of the activity, hoping that this one can contribute to the socio-economic and cultural development of an oasis in decline. In this context, various projects were undertaken, in particular with the assistance of MON-3, the Spanish co-operation organization, and " Africa 70 ", an Italian NGO. The French team participated in the realization of descriptive panels, by producing texts and maps for the panels placed at the entrance of the city and the entrance of one of the $7 \mathrm{ksour}$, the ksar Loudaghir. In the future, it is also planned to prepare tourist routes, focusing on areas studied by the French researchers, in particular the archaeology and the palm grove. In this context, a GIS would allow to exploit the scientific and patrimonial data to develop the Figuig's heritage. The GIS does indeed facilitate the identification and the location of the main resources and makes it also possible to prevent the potential negative impacts of the tourist activity. Concretely, the work led until now led to the implementation of the tourist descriptive panels. The Paris 7-ENSPAVS team also proposed a tourist route in the Ksar Loudaghir, which could be extended to the other ksour. This project was launched in 2007 by Sarah Khazindar and Camille Vallat within the framework of their study, and finalized by Nabila Gouméziane in 2009. It consists in setting up a signalling system following rather simple graphics standards, which can guide and direct the tourists and which will allow them to move inside the Ksar without difficulty by signalling the pedestrian route. Georeferenced backgrounds, as well as the located inventories of remarkable buildings, have been used to realize the tourist maps, panels and thematic routes in partnership with the NGO Africa ' 70 .

\subsection{A tool of cooperation between local actors, the Moroccan State and the actors of cooperation}

A training campaign in the practice of the GIS for the various agents of the municipality and the offices of cooperation was launched in parallel with these scientific initiatives. The purpose is to put the GIS at the disposal of local actors so 
that it constitutes a common tool of management of the policy of heritage protection and urban development. In the context of the UNESCO nomination file, the GIS, by its capacity to represent the perimeter to be protected, can be a communication tool between experts, local actors and the Moroccan central authorities. Indeed, the municipality has to convince the Ministry of Culture of the importance to register the oasis on the indicative list and to support the file to be submitted to the UNESCO. The GIS will thus constitute the "pivot" of the implementation of the management plan described in the submission file. It will make good governance possible to ensure transparency, sharing and understanding of the constraints which will inevitably accompany the protective measures of the heritage.

\section{CONCLUSION}

In this study, we have shown the potential of the GIS in several respects. The GIS makes it possible to gather varied scientific information and to produce thematic mappings. It is characterized by multiple applications. It is at the same time a scientific, heritage, environmental and tourist management tool, at the disposal of various users. Within the framework of this paper, we particularly insisted on the importance of the GIS in the preparation of the nomination file for the inscription of the oasis of Figuig on UNESCO's world heritage list. Considering the difficulty for the local actors to understand and to bring to a successful conclusion the process of inscription on the WHL, the GIS also turned out to be a communications tool, allowing the scientific team to collect and to represent scattered information, to explain the relevance of a classification as world heritage and to propose concrete measures. The debates concerning the determination of the buffer zone bear witness to the multipurpose nature of the GIS. For the scientists, it allowed to collect structure and analyze a scattered documentation. It opens up future prospects researches, in particular on the archaeological level, where the GIS could be the support for the management and study of the material and the information, as well as a tool suggesting digital restorations of places and monuments. This globalizing, structuring aspect of the GIS comes along with an evolutionary and flexible character, as the GIS can adapt itself to take account of new pieces of information. As a matter of fact, the GIS testify of the plasticity of the digital information. Finally, and it is one of the objectives of the French team cooperating with the municipality of Figuig, the GIS could be considered as a good governance tool. Through the training of local actors, it is a means of communication and action, spreading information and raising awareness of the local populations. It could also help to develop top-down approaches to the management of the heritage and of the urban development of the oasis.

\section{REFERENCES}

[1] Abbou, A., Boilève, M.: Figuig, la ville oasis du Maroc Oriental, Paris, La croisée des chemins, 2009.

Bencherifa, A., Popp, H.: L'oasis de Figuig : persistance et changement, Rabat, Publications de la Faculté des lettres et des Sciences humaines, Série : essais et études n³, 1992.

[2] Djenandar, E H., Contribution à la lecture des écosystèmes des paysages des oasis de la haute Zousfana : Béni Ounif (Algérie occidentale), Rennes, Thèse de géographie, Université Renne 2, 2003.

[3] Eastman, R.: Un SIG en mode image: Idrisi. trad C. Colle, Fribourg, Université de Fribourg, 1995.

[4] Forman, R.T.T., Godron, M.: Landscape ecology, New York, John Wiley, 1986.

[5] Gautier, E. F.: La source de Tzaddert à Figuig, Annales de Géographie, t. 26, nº144 (1917), 453-466.

[6] Godron, M.: Ecologie de la végétation terrestre, Paris, Masson, 1984.

[7] Gonzalez Villaescusa R., Pichard Cl., Rapport préliminaire de fouille: Première évaluation du potentiel archéologique du qsar Ouled Jaber (FIGUIG), (7 - 20 octobre 2009), Paris, Université Paris Diderot, 2009.

[8] Goumeziane N.: Projet de demande d'inscription de l'oasis de Figuig au patrimoine de l'humanité par l'UNESCO, Mémoire du Master 2 VAP, Université Paris Diderot, sous la direction de J-P Vallat. 2010.

[9] Grosso, E.: Proposition pour une gestion unifiée des données anciennes, SAGEO, Vol. 7 (2009), 1-16.

[10] Janty G., Cohen M., Godron M.: La palmeraie de Figuig, paysage de l'eau, patrimoine de l'Humanité ?, Acte colloques international LPED / IMEP: "Usages écologiques, économiques et sociaux de l'eau agricole en Méditerranée: quels enjeux pour quels services?" Université de Provence, Centre Saint Charles, Marseille, France 2021 janvier 2011.

[11] Laurini, R., Milleret-Raffort, F.: Les bases de données en géomatique, Paris, Editions Hermès, 1993.

[12] Mizbar, S.: Résistances oasiennes au Maroc, aux racines du développement. Recherche sur l'évolution des oasis dans la province de Figuig, Paris, Thèse, Université Paris 7 Denis Diderot, 2004.

[13] Pantazis, D., Donnay, J.P.: La conception de SIG, Paris, Editions Hermès, 1996.

[14] Pumain, D., Saint Julien, Th.: L'analyse spatiale, Paris, Armand Collin, 2010.

[15] Ruas A.(dir.): Généralisation et représentation multiple, Paris, Editions Hermès, 2002.

[16] Zaïd, O., Figuig (Maroc Oriental) : L'aménagement traditionnel et les mutations de l'espace oasien, Paris, Thèse, Université Paris 1, 2 vol., 1992. 